\title{
CANE PRUNING INTENSITY OF VINE AS A SUBSTANTIAL FACTOR INFLUENCING PHYSICO-CHEMICAL ATTRIBUTES OF BERRIES CULTIVAR 'REGENT'
}

\section{INTENSYWNOŚĆ CIĘCIA ŁOZY WINOROŚLI JAKO ISTOTNY CZYNNIK WPŁYWAJACCY NA WŁAŚCIWOŚCI FIZYKOCHEMICZNE WINOGRON ODMIANY 'REGENT'}

Department of Horticulture, West Pomeranian University of Technology Szczecin, Poland

\begin{abstract}
Streszczenie. Badania były skoncentrowane na ocenie jakości winogron odmiany 'Regent'. Winorośl prowadzoną w systemie pojedynczego sznura Guyot poddano zabiegom cięcia o trzech intensywnościach: 4, 6 lub 8 pąków na łozę. Owoce zebrano w trzech kolejnych sezonach (w latach 2013-2015) w stacji badawczej Zachodniopomorskiego Uniwersytetu Technologicznego w Szczecinie. Winogrona 'Regent' analizowano pod kątem właściwości fizycznych i chemicznych, tj. masy gron i 100 owoców, całkowitej zawartości substancji rozpuszczalnych, kwasowości, pH, polifenoli, składników odżywczych (Ca, Cu, Fe, K, Mg, Mn, N, P, Zn) i metali ciężkich $(\mathrm{Cd}, \mathrm{Pb})$. Wyniki pokazały, że intensywność cięcia łozy winorośli odmiany 'Regent' miała istotny wpływ na jakość owoców, z wyjątkiem masy gron, kwasowości i pH. W przypadku masy 100 owoców, całkowitej zawartości substancji rozpuszczalnych i większości pierwiastków notowano wzrost wraz ze wzrostem intensywności cięcia. Z kolei najlżejsze cięcie doprowadziło do najwyższej koncentracji polifenoli, K, Cu i Fe w winogronach.
\end{abstract}

Key words: bud load, pruning intensity, quality of berries.

Słowa kluczowe: liczba pąków, intensywność cięcia, jakość winogron.

\section{INTRODUCTION}

It is generally known that grape quality is influenced by many factors; environmental conditions, e.g. sunlight and temperature (Keller 2010), and viticulture management practices, e.g. rootstock/scion combination (Keller et al. 2012), irrigation (Tangolar et al. 2015), pruning (Kumar et al. 2017), leaf removal (Drenjančević et al. 2017). However, pruning has the maximum influence on the final yield and quality of a cultivar among the different cultural operations in grapes. And berry quality highly depends on the precision of the pruning (Brighenti et al. 2017).

Many researchers have been studied the effect of bud load level on the quality of grapes and wine. Coletta et al. (2014) found that training system and bud load can affect the polyphenolic compounds concentration of the red wines, and therefore, the total antioxidant capacity. Baiano and Terracone (2012) concluded, that the changes in the quality of grapes

Corresponding author - Adres do korespondencji: Kamila Pachnowska, Department of Horticulture, West Pomeranian University of Technology, Szczecin, Juliusza Słowackiego 17, 71-434 Szczecin, Poland, e-mail: kamila.mijowska@zut.edu.pl 
by reducing the bud load were not always positive, i.e. by decreasing pulp antioxidant activity of cultivar 'Beogradska besemena'. On the other hand, increasing the number of buds per vine may lead to e.g. decreasing of bud fertility and fruitfulness, and reducing cluster weight (Fawzi et al. 2010). However, researchers indicate that the effect of bud load is depended on cultivars/varieties, and therefore general recommendation for pruning intensity cannot be made (Bhosale et al. 2010; Baiano and Terracone 2012; Coletta et al. 2014). Various sensitivity to the pruning level probably depends mainly on different phenotypic behaviour (Baiano and Terracone 2012). Thus, although pruning is a technological stage extensively studied, it can be optimised for each variety according to the production destination, environmental conditions and vineyard management (Dobrei et. al 2016).

In this study, three different intensities of pruning were tested on the 'Regent' vines trained with Single Guyot training system, which is a cane-pruned method with spur. The cane buds grow into shoots that produce the yield, in turn the spur buds grow into shoots that can be used as canes in the following vegetative season (Brighenti et al. 2017). Vine cultivated in traditional French vineyards is typically pruned to one cane with six to eight buds and one spur with two buds. The number of buds depends on the regional tradition and the appellation côntrolée laws. For example, in Côtes du Rhône eight buds per cane may be left on 'Syrah'. However, in Bordeaux seven buds is the maximum for 'Sémillon'. In turn, in Sauternes six for 'Muscadelle' (Robinson and Harding 2015).

This article demonstrate the impact of cane pruning intensity on the physico-chemical attributes of berries cultivar 'Regent' grown in the cool climate condition of North-Western Poland. Basic parameters such as cluster weight, weight of 100 berries, total soluble solids, titratable acidity, $\mathrm{pH}$ and polyphenols were determined. In addition, elemental composition of berries was studied, i.e. $\mathrm{Ca}, \mathrm{Cu}, \mathrm{Fe}, \mathrm{K}, \mathrm{Mg}, \mathrm{Mn}, \mathrm{N}, \mathrm{P}$ and $\mathrm{Zn}$ were analysed among mineral nutrients, whereas $\mathrm{Cd}$ and $\mathrm{Pb}$ were analysed among heavy metals.

\section{MATERIAL AND METHODS}

\section{Characteristics of the experimental field, plant material and soil}

The field experiment was conducted in three consecutive seasons of the years 2013-2015 in the research station of the West Pomeranian University of Technology in Szczecin (Poland). The research station is located in the North-Western part of Poland in the Szczecin Lowland $\left(53^{\circ} 40^{\prime} \mathrm{N}, 14^{\circ} 46^{\prime} \mathrm{E}\right)$ at a distance of approximately $65 \mathrm{~km}$ from the Baltic Sea.

The object of the study was vine cultivar 'Regent', which was grafted on 'SO4' rootstock and planted in 2010 with a North-South row orientation at $2.3 \times 1 \mathrm{~m}$. The vines were cane pruned with a Single Guyot training system with vertical shoot positioned and two clusters each.

The soil in the vineyard was an agricultural soil with a natural profile, and it was detailed characterised in previous paper (Mijowska et al. 2017). Nitrogen fertilisation at $60 \mathrm{~kg} \mathrm{~N}$ and a magnesium sulfate in the dose of $80 \mathrm{~kg} \mathrm{Mg}$ per hectare were applied annual in the spring at a stage of bud swelling (BBCH 01). Pest treatment and other standard vineyard management practices were carried out during all growing seasons.

\section{Weather conditions}

In our previous paper (Mijowska et al. 2017), basic weather conditions during the growing season (April-October) in the years 2013-2015 with reference to the multi-year period 
(1951-2012) were described. Generally, the rainfall during the growing period of 2015 was relevantly lower, while during the 2014 higher, comparing to other years of study and multiyear period. Additionally, May and June of 2015 were characterised by lower temperature, while August of 2015 by much higher temperature, in relation to other experimental years and mean of years 1951-2012.

\section{Experiment design and berries analyses}

Pruning was performed with three intensity levels of 4,6 or 8 buds per cane. The experimental treatments were arranged in a randomised complete block design. Each experimental unit was consisted of ten vines. Berries were collected on the first decade of October in successive seasons, with an average berry maturity of $20.5^{\circ}$ Brix.

Ten clusters per treatment were randomly chosen to calculate cluster weight. The same material was used to determine other parameters. The measurements of berries weight, total soluble solids (TSS), titratable acidity (TA) and $\mathrm{pH}$ were performed on three replicates of 100 fresh berries randomly chosen. All berries parameters were conducted immediately after harvest. The weights of clusters and berries were determined using WPX 4500 (RADWAG, Radom, Poland) electronic scales ( $0.1 \mathrm{~g}$ accuracy). TSS was measured as ${ }^{\circ}$ Brix with a PAL-1 refractometer (Atago, Tokyo, Japan). TA was evaluated by titration of a water extract of juice with $0.1 \mathrm{~N} \mathrm{NaOH}$ to an end point of $\mathrm{pH} 8.1$. The $\mathrm{pH}$ of the juice samples was determined using a pH-meter (Elmetron 501, Zabrze, Poland).

Polyphenols were measured by the UPLC-PDA/MS method on three replicates of 25 randomly chosen berries, which were kept frozen at $-27^{\circ} \mathrm{C}$ until analysis. Extraction procedure and identification of phenolic compounds were performed according to the methodology of Oszmiański et al. (2013).

The estimation of the elements content in dry weight plant was carried out in accordance with the Polish Standard (IUNG 1990) using certified reagents. Berries of 'Regent' were dried at a temperature of $105^{\circ} \mathrm{C}$. $\mathrm{Ca}, \mathrm{K}, \mathrm{Mg}, \mathrm{N}$ and $\mathrm{P}$ were analysed after wet mineralisation in $\mathrm{H}_{2} \mathrm{SO}_{4}$ (96\%) and $\mathrm{HClO}_{4}(70 \%)$. The content of $\mathrm{Cd}, \mathrm{Cu}, \mathrm{Fe}, \mathrm{Mn}, \mathrm{Pb}$ and $\mathrm{Zn}$ was evaluated after mineralisation in $\mathrm{HNO}_{3}(65 \%)$ and $\mathrm{HClO}_{4}(70 \%)$ in a ratio $3: 1$. The total nitrogen concentration was determined by the Kjeldahl distillation method using a Vapodest 30 (Gerhardt $\mathrm{GmbH}$, Germany). The content of $\mathrm{K}$ was measured with the atomic emission spectrometry, whereas $\mathrm{Ca}, \mathrm{Cd}, \mathrm{Cu}, \mathrm{Fe}, \mathrm{Mg}, \mathrm{Mn}, \mathrm{Pb}$ and $\mathrm{Zn}$ contents with the flame atomic absorption spectroscopy using iCE 3000 Series (Thermo Fisher Scientific, UK). Phosphorus (P) was assessed by the colourimetric method on a Spekol 221 spectrophotometer (Carl Zeiss, Germany). All tests were performed each year in three replications.

\section{Statistical analysis}

All data were analysed using Statistica 12.5 (Statsoft Polska, Cracow, Poland). The results were subjected to one-factor variance analysis (ANOVA), performed separately for each year. The average data of pruning intensity were analysed statistically by means of synthesis from years. Mean comparisons were evaluated by Tukey's least significant difference test (LSD) at $p<0.05$ significance level. 


\section{RESULTS AND DISCUSSION}

\section{The impact of weather conditions on the quality of berries}

The weather conditions during three years of study had significant influence on the general accumulation of all tested parameters in berries, and large differences occurred between seasons. The concentrations of basic quality attributes, such as cluster weight, weight of 100 berries, TSS, TA, pH and polypehnols are summarised in Table 1.

Table 1. Basic parameters of 'Regent' berries in three years of study (2013-2015) harvested from vine treated with three different pruning intensities (bud load level per cane: $4,6,8$ )

Tabela 1. Podstawowe parametry winogron odmiany 'Regent' $w$ trakcie trzech lat badań (2013-2015), zebranych z winorośli przy różnej intensywności cięcia (liczba latorośli na łozie: 4, 6, 8)

\begin{tabular}{|c|c|c|c|c|}
\hline \multirow{2}{*}{$\begin{array}{l}\text { Year } \\
\text { Rok }\end{array}$} & \multicolumn{3}{|c|}{ Bud load - Liczba latorośli na łozie } & \multirow{2}{*}{$\begin{array}{l}\text { Mean } \\
\text { Średnia }\end{array}$} \\
\hline & 4 & 6 & 8 & \\
\hline \multicolumn{5}{|c|}{ Cluster weight - Masa gron [g] } \\
\hline 2013 & $201.3 b^{*}$ & $176.4 \mathrm{a}$ & $171.2 \mathrm{a}$ & $183.0 \mathrm{~B}$ \\
\hline 2014 & $98.3 \mathrm{a}$ & 95.7 a & 82.7 a & $92.2 \mathrm{~A}$ \\
\hline 2015 & $164.7 \mathrm{ab}$ & $181.4 \mathrm{~b}$ & $158.3 \mathrm{a}$ & $168.1 \mathrm{~B}$ \\
\hline \multicolumn{5}{|c|}{ Weight of 100 berries - Masa 100 jagód [g] } \\
\hline 2013 & $147 \mathrm{a}$ & $165 \mathrm{~b}$ & $150 \mathrm{ab}$ & $154 \mathrm{~A}$ \\
\hline 2014 & $233 b$ & $240 \mathrm{~b}$ & $200 a$ & $224 \mathrm{~B}$ \\
\hline 2015 & $147 \mathrm{a}$ & $163 a$ & $154 \mathrm{a}$ & $155 \mathrm{~A}$ \\
\hline \multicolumn{5}{|c|}{$\begin{array}{c}\text { Total soluble solids - Całkowita zawartość substancji } \\
\text { rozpuszczalnych }\left[{ }^{\circ} \text { Brix }\right]\end{array}$} \\
\hline 2013 & $20.0 \mathrm{~b}$ & $19.3 \mathrm{a}$ & 18.9 a & $19.4 \mathrm{~A}$ \\
\hline 2014 & $20.7 a b$ & $21.0 \mathrm{~b}$ & $20.5 \mathrm{a}$ & 20.7 B \\
\hline 2015 & $22.0 \mathrm{~b}$ & $21.5 \mathrm{~b}$ & $20.8 \mathrm{a}$ & $21.4 \mathrm{C}$ \\
\hline \multicolumn{5}{|c|}{$\mathrm{pH}-\mathrm{Odczyn} \mathrm{pH}$} \\
\hline 2013 & $3.34 \mathrm{a}$ & $3.25 \mathrm{a}$ & $3.19 \mathrm{a}$ & $3.26 \mathrm{~A}$ \\
\hline 2014 & $3.86 \mathrm{a}$ & $3.82 \mathrm{a}$ & $3.77 \mathrm{a}$ & $3.82 \mathrm{~B}$ \\
\hline 2015 & $3.27 \mathrm{a}$ & $3.19 \mathrm{a}$ & $3.21 \mathrm{a}$ & $3.22 \mathrm{~A}$ \\
\hline \multicolumn{5}{|c|}{ Titratable acidity - Kwasowość $\left[\mathrm{g} \cdot \mathrm{dm}^{3}\right]$} \\
\hline 2013 & $8.89 \mathrm{a}$ & $9.60 \mathrm{~b}$ & $10.23 \mathrm{c}$ & $9.57 \mathrm{C}$ \\
\hline 2014 & $8.08 \mathrm{~b}$ & $6.93 \mathrm{a}$ & $8.00 \mathrm{~b}$ & $7.67 \mathrm{~A}$ \\
\hline 2015 & $8.22 \mathrm{a}$ & $9.07 \mathrm{~b}$ & $8.53 a b$ & $8.61 \mathrm{~B}$ \\
\hline \multicolumn{5}{|c|}{ Polyphenols - Polifenole [mg · $\left.100 \mathrm{~g}^{-1} \mathrm{FW}\right]$} \\
\hline 2013 & $529 \mathrm{a}$ & $561 \mathrm{~b}$ & $606 c$ & $565 \mathrm{~A}$ \\
\hline 2014 & $598 a b$ & $582 \mathrm{a}$ & $627 \mathrm{~b}$ & 602 B \\
\hline 2015 & $594 \mathrm{a}$ & $627 \mathrm{a}$ & $700 \mathrm{~b}$ & $640 \mathrm{C}$ \\
\hline
\end{tabular}

*Means having same letter were not significantly different by Tukey's comparison at $p<0.05$ level. Lowercase letters indicate the means for each year, capital letters main factors - Średnie oznaczone tymi samymi literami nie różniły się istotnie, według testu Tukeya, na poziomie $p<0,05$. Małe litery oznaczają średnie dla poszczególnych lat, duże litery - główne czynniki.

The year of 2014 was chcarcterised by the lowest cluster weight $(92.2 \mathrm{~g})$ and TA $\left(7.67 \mathrm{~g} \cdot \mathrm{dm}^{3}\right)$, but the highest weight of 100 berries $(224 \mathrm{~g})$ and $\mathrm{pH}$ (3.82). Regardless of the pruning intensity, the greatest content of polyphenols was found in berries harvested in 2015 (640 mg $\left.\cdot 100 \mathrm{~g}^{-1} \mathrm{FW}\right)$. This is consistet with results of our other experiment, that was conducted with cultivar 'Regent' grafted on different rootstocks (Mijowska et al. 2017). Each rootstock and own-rooted vines showed the highest concentration of polyphenols in berries harvested in 2015. In addition, this research indicate that the year of 2015 was characterised by the highest level of TSS 
(21.4 ${ }^{\circ}$ Brix). Looking at the particular year of study, pruning intensity had statistically significant impact on most parameters, with the exception of $\mathrm{pH}$ in all experimental years, cluster weight in 2014, and weight of 100 berries in 2015. In the paper of Kurtural et al. (2006), authors noted that differences occurring between cluster and berry weights, TSS, TA and $\mathrm{pH}$ were ambiguous, with statistically significance or insignificance depending on the year of the study and/or vineyard location. In turn, Heazlewood et al. (2006) found a relevant year effect for each of the yield components (cluster and berry weight) of 'Pinot Noir' cultivated in a cool climate wine area of Tasmania (Australia).

The weather conditions had substantial impact on the concentration of nutrients and heavy metals in berries as well. The results of macronutrients $(\mathrm{Ca}, \mathrm{K}, \mathrm{Mg}, \mathrm{N}$ and $\mathrm{P}$ ) are presented in Table 2, whereas the results of micronutrients $(\mathrm{Cu}, \mathrm{Fe}, \mathrm{Mn}$ and $\mathrm{Zn})$ and heavy metals $(\mathrm{Cd}, \mathrm{Pb})$ are showed in Table 3. The accumulation of $\mathrm{Ca}, \mathrm{K}$ and $\mathrm{Mg}$ was diminished in 2013 comparing to 2014 and 2015. However, this year was characterised by the greatest level of N, Cu and Fe. In 2014 was noted the highest concentration of $\mathrm{K}$ and $\mathrm{P}$ and the lowest of $\mathrm{Cu}$ and $\mathrm{Mn}$. In turn, weather conditions of 2015 led to the highest uptake of $\mathrm{Ca}, \mathrm{Mn}, \mathrm{Pb}$ and $\mathrm{Zn}$, and decreased accumulation of $\mathrm{P}, \mathrm{Cd}$ and Fe. Bud load effect showed statistical meaning in the content of all macroelements during each year of study. Similarly, in the case of microelements and heavy metals, however, pruning severity had no influence on the accumulation of Cd in 2013 and 2014, as well $\mathrm{Cu}$ and $\mathrm{Fe}$ in 2015.

Table 2. Macronutrient composition ( $\left.\mathrm{g} \cdot \mathrm{kg}^{-1}\right)$ of 'Regent' berries in three years of study (2013-2015) harvested from vine treated with three different pruning intensity (bud load level per cane: $4,6,8$ )

Tabela 2. Zawartość makroelementów $\left(\mathrm{g}^{\cdot} \mathrm{kg}^{-1}\right) \mathrm{w}$ winogronach odmiany 'Regent' $\mathrm{w}$ trakcie trzech lat badań (2013-2015), zebranych z winorośli przy różnej intensywności cięcia (liczba latorośli na łozie: $4,6,8)$

\begin{tabular}{|c|c|c|c|c|}
\hline \multirow{2}{*}{$\begin{array}{l}\text { Year } \\
\text { Rok }\end{array}$} & \multicolumn{3}{|c|}{ Bud load - Liczba latorośli na łozie } & \multirow{2}{*}{$\begin{array}{l}\text { Mean } \\
\text { Średnia }\end{array}$} \\
\hline & 4 & 6 & 8 & \\
\hline \multicolumn{5}{|c|}{$\mathrm{Ca}$} \\
\hline 2013 & $1.15 b^{*}$ & $0.70 \mathrm{a}$ & $0.71 \mathrm{a}$ & $0.85 \mathrm{~A}$ \\
\hline 2014 & $1.08 \mathrm{c}$ & $0.94 \mathrm{~b}$ & $0.80 \mathrm{a}$ & 0.94 B \\
\hline 2015 & $1.15 b$ & $1.08 \mathrm{~b}$ & $0.92 \mathrm{a}$ & $1.04 \mathrm{C}$ \\
\hline \multicolumn{5}{|c|}{$\mathrm{K}$} \\
\hline 2013 & $8.31 \mathrm{a}$ & $10.39 \mathrm{~b}$ & $11.11 \mathrm{c}$ & $9.94 \mathrm{~A}$ \\
\hline 2014 & $14.94 \mathrm{a}$ & $16.40 \mathrm{~b}$ & $16.16 \mathrm{~b}$ & $15.83 \mathrm{C}$ \\
\hline 2015 & $9.67 \mathrm{a}$ & $11.94 \mathrm{~b}$ & $12.64 \mathrm{c}$ & $11.42 \mathrm{~B}$ \\
\hline \multicolumn{5}{|c|}{$\mathrm{Mg}$} \\
\hline 2013 & $0.31 \mathrm{~b}$ & $0.29 a b$ & $0.25 \mathrm{a}$ & $0.28 \mathrm{~A}$ \\
\hline 2014 & $0.46 \mathrm{~b}$ & $0.47 \mathrm{~b}$ & $0.40 \mathrm{a}$ & $0.44 \mathrm{~B}$ \\
\hline 2015 & $0.43 \mathrm{~b}$ & $0.43 \mathrm{~b}$ & $0.33 a$ & $0.40 \mathrm{~B}$ \\
\hline \multicolumn{5}{|c|}{$\mathrm{N}$} \\
\hline 2013 & $7.78 \mathrm{~b}$ & $6.86 \mathrm{a}$ & $6.51 \mathrm{a}$ & $7.05 \mathrm{~B}$ \\
\hline 2014 & $6.39 c$ & $6.12 b$ & $5.03 \mathrm{a}$ & $5.85 \mathrm{~A}$ \\
\hline 2015 & $5.70 \mathrm{~b}$ & $5.74 \mathrm{~b}$ & $5.01 \mathrm{a}$ & $5.48 \mathrm{~A}$ \\
\hline \multicolumn{5}{|c|}{$P$} \\
\hline 2013 & $2.25 \mathrm{c}$ & $2.13 \mathrm{~b}$ & $1.99 \mathrm{a}$ & $2.12 \mathrm{~B}$ \\
\hline 2014 & $2.73 \mathrm{a}$ & $2.85 \mathrm{~b}$ & $2.76 a b$ & $2.78 \mathrm{C}$ \\
\hline 2015 & $2.11 \mathrm{c}$ & $1.94 \mathrm{~b}$ & $1.66 \mathrm{a}$ & $1.90 \mathrm{~A}$ \\
\hline
\end{tabular}

*Explanations see Table 1. - Objaśnienia w tab. 1. 
Table 3. Micronutrients composition and heavy metals $\left(\mathrm{mg} \cdot \mathrm{kg}^{-1}\right)$ of 'Regent' berries in three years of study (2013-2015) harvested from vine treated with three different pruning intensity (bud load level per cane: $4,6,8)$

Tabela 3. Zawartość mikroelementów i metali ciężkich $\left(\mathrm{mg} \cdot \mathrm{kg}^{-1}\right)$ w winogronach odmiany 'Regent' w trakcie trzech lat badań (2013-2015), zebranych z winorośli przy różnej intensywności cięcia (liczba latorośli na łozie: $4,6,8)$

\begin{tabular}{|c|c|c|c|c|}
\hline \multirow{2}{*}{$\begin{array}{l}\text { Year } \\
\text { Rok }\end{array}$} & \multicolumn{3}{|c|}{ Bud load - Liczba latorośli na łozie } & \multirow{2}{*}{$\begin{array}{c}\text { Mean } \\
\text { Średnia }\end{array}$} \\
\hline & 4 & 6 & 8 & \\
\hline \multicolumn{5}{|c|}{ Micronutrients - Mikroelementy } \\
\hline \multicolumn{5}{|c|}{$\mathrm{Cu}$} \\
\hline 2013 & $4.29 \mathrm{a}^{*}$ & $4.57 \mathrm{a}$ & $5.05 \mathrm{~b}$ & $4.64 \mathrm{C}$ \\
\hline 2014 & $2.35 \mathrm{a}$ & $2.46 a b$ & $2.61 \mathrm{~b}$ & $2.47 \mathrm{~A}$ \\
\hline 2015 & $3.05 \mathrm{a}$ & $3.24 \mathrm{a}$ & $3.18 \mathrm{a}$ & $3.16 \mathrm{~B}$ \\
\hline \multicolumn{5}{|c|}{$\mathrm{Fe}$} \\
\hline 2013 & $16.84 \mathrm{a}$ & $19.51 \mathrm{ab}$ & $23.29 \mathrm{~b}$ & $19.88 \mathrm{C}$ \\
\hline 2014 & 14.99 a & $18.52 \mathrm{~b}$ & $19.51 \mathrm{~b}$ & $17.67 \mathrm{~B}$ \\
\hline 2015 & $13.08 \mathrm{a}$ & $13.49 \mathrm{a}$ & $15.80 \mathrm{a}$ & $14.12 \mathrm{~A}$ \\
\hline \multicolumn{5}{|c|}{$\mathrm{Mn}$} \\
\hline 2013 & $6.86 \mathrm{c}$ & $5.05 \mathrm{~b}$ & $3.91 \mathrm{a}$ & $5.27 \mathrm{~B}$ \\
\hline 2014 & 5.32 b & $5.13 \mathrm{~b}$ & $4.12 \mathrm{a}$ & $4.86 \mathrm{~A}$ \\
\hline 2015 & $7.09 \mathrm{c}$ & $6.28 \mathrm{~b}$ & $5.36 \mathrm{a}$ & $6.24 \mathrm{C}$ \\
\hline \multicolumn{5}{|c|}{$\mathrm{Zn}$} \\
\hline 2013 & $5.96 \mathrm{~b}$ & $5.35 \mathrm{a}$ & $5.30 \mathrm{a}$ & $5.54 \mathrm{~A}$ \\
\hline 2014 & $5.24 \mathrm{a}$ & $6.21 \mathrm{~b}$ & $6.40 \mathrm{~b}$ & $5.95 \mathrm{~A}$ \\
\hline 2015 & $8.43 b$ & $8.42 \mathrm{~b}$ & $6.60 \mathrm{a}$ & $7.82 \mathrm{~B}$ \\
\hline \multicolumn{5}{|c|}{ Heavy metals - Metale ciężkie } \\
\hline \multicolumn{5}{|c|}{$\mathrm{Cd}$} \\
\hline 2013 & $0.017 \mathrm{a}$ & $0.017 \mathrm{a}$ & $0.015 \mathrm{a}$ & 0.016 \\
\hline 2014 & $0.015 a$ & $0.014 a$ & $0.014 a$ & 0.014 \\
\hline 2015 & 0.012 & $<0.01$ & $<0.01$ & - \\
\hline \multicolumn{5}{|c|}{$\mathrm{Pb}$} \\
\hline 2013 & $0.191 \mathrm{~b}$ & $0.189 \mathrm{~b}$ & $0.167 \mathrm{a}$ & $0.182 \mathrm{~A}$ \\
\hline 2014 & $0.162 \mathrm{a}$ & $0.180 \mathrm{~b}$ & $0.184 \mathrm{~b}$ & $0.175 \mathrm{~A}$ \\
\hline 2015 & $0.231 \mathrm{~b}$ & $0.213 \mathrm{a}$ & $0.204 \mathrm{a}$ & $0.216 \mathrm{~B}$ \\
\hline
\end{tabular}

*Explanations see Table 1. - Objaśnienia w tab. 1.

\section{Physico-chemical attributes of berries}

Figure 1 presents basic quality parameters of berries cultivar 'Regent' as an average of three years study (2013-2015), ie. cluster weight, weight of 100 berries, total soluble solids, titratable acidity, $\mathrm{pH}$ and polyphenols. The weight of clusters varied from 137.4 to $154.8 \mathrm{~g}$, and there was no significant meaning between pruning intensity. This is in contradiction with other authors' findings, that increasing bud load reduced cluster weight (Fawzi et al. 2010; Khamis et al. 2017). However, it should be take into account, that our experiment include cluster thinning levels of two clusters per shoot. Similarly as in the case of cluster weight, bud load treatment has no statistical influence on TA $\left(8.40-8.92 \mathrm{~g} \cdot \mathrm{dm}^{3}\right)$ and $\mathrm{pH}(3.39-3.49)$ levels. Bindon et al. (2008) reported that in the case of 'Shiraz' cultivated in South Australia, these parameters were unaltered by pruning level as well. 


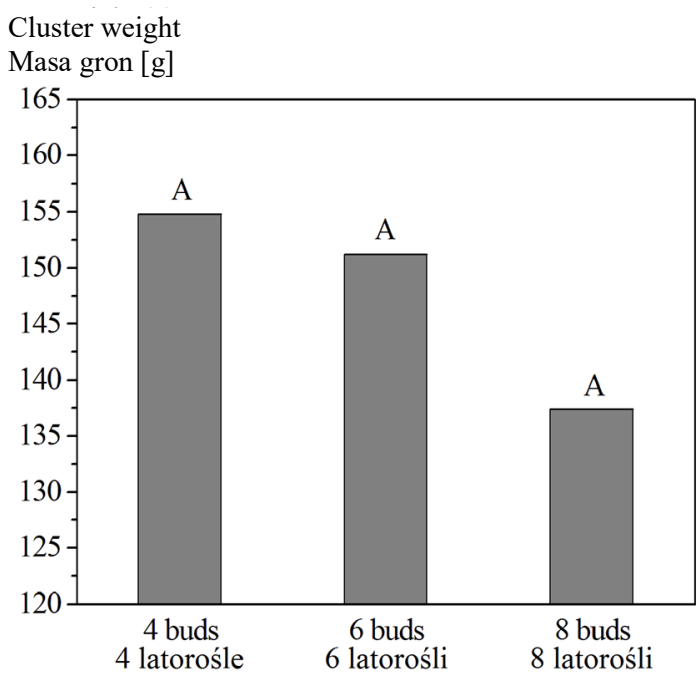

Total soluble solids

Całkowita zawartość substancji rozpuszczalnych [ ${ }^{\circ}$ Brix]
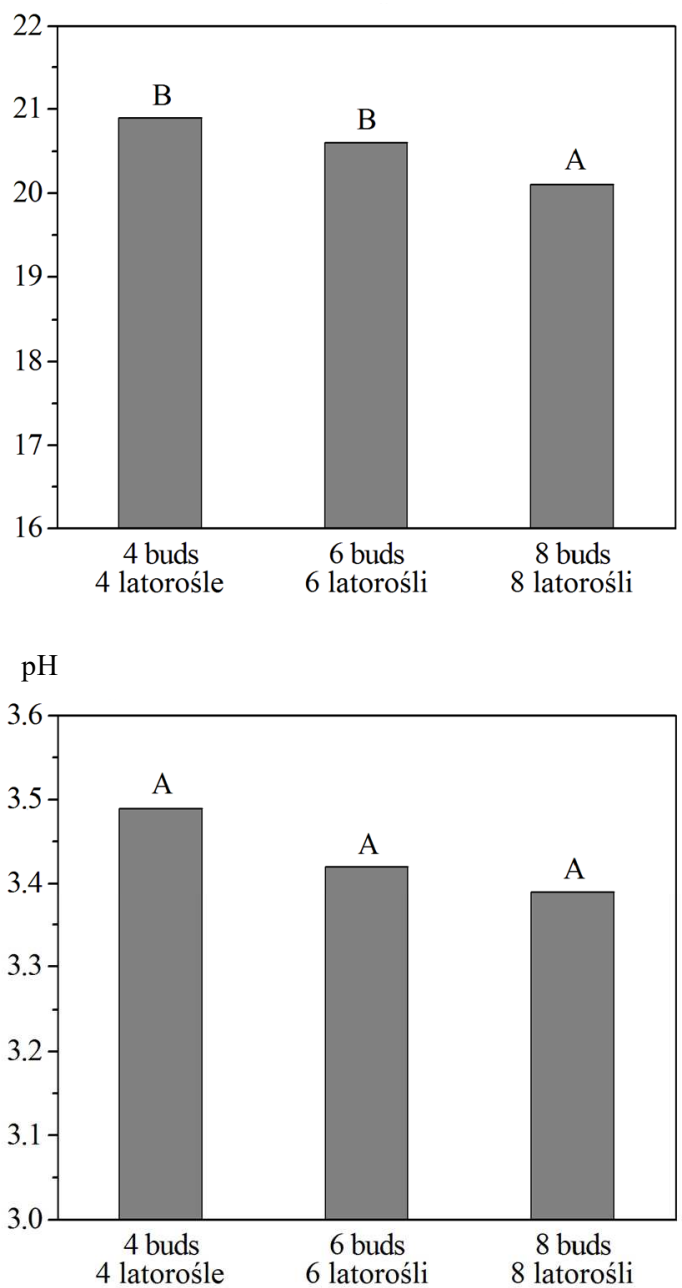

Weight of 100 berries

Masa 100 jagód [g]

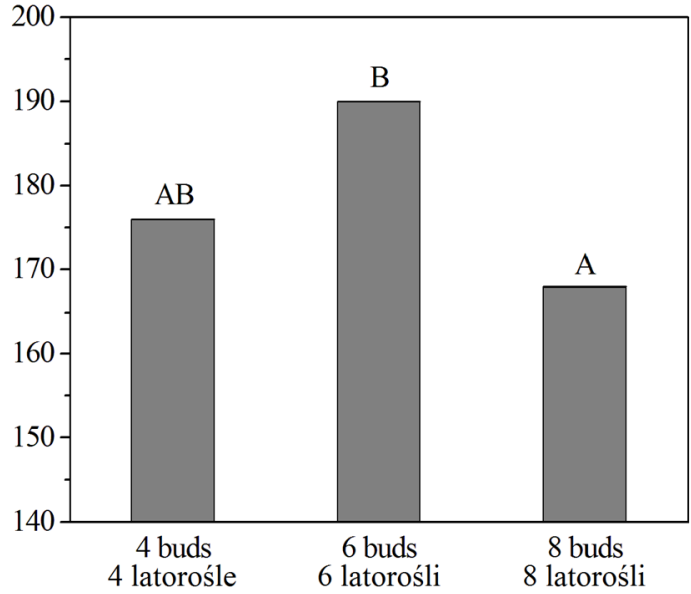

Titratable aciddity

Kwasowość $\left[\mathrm{g} \cdot \mathrm{dm}^{3}\right]$

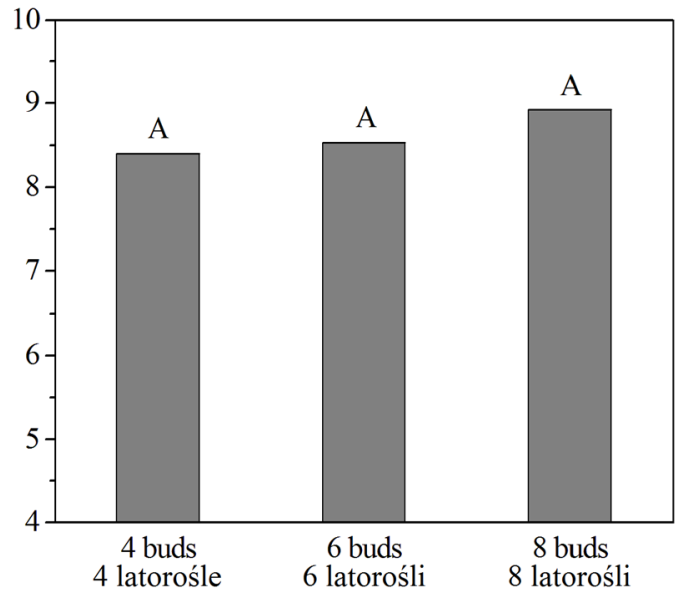

Polyphenols

Polifenole [mg $\left.\cdot 100 \mathrm{~g}^{-1} \mathrm{FW}\right]$

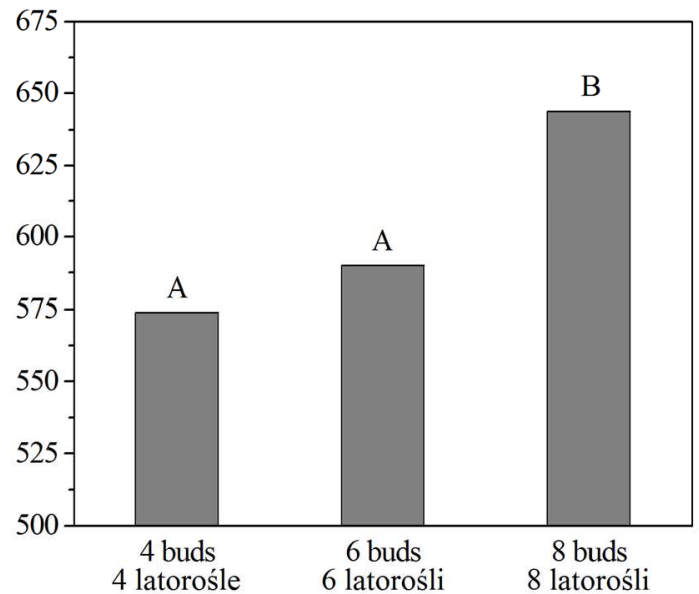

Fig. 1. Basic parameters of 'Regent' berries depending on vine pruning intensity (bud load level per cane: $4,6,8$ ); as the average of years 2013-2015. Means having same letter were not significantly different by Tukey's comparison at $p<0.05$ level

Ryc. 1. Podstawowe parametry winogron odmiany 'Regent' $w$ zależności od intensywności cięcia winorośli (liczba latorośli na łozie: 4, 6, 8); średnia z lat 2013-2015. Średnie oznaczone tymi samymi literami nie różniły się istotnie według testu Tukeya na poziomie $p<0,05$ 
Our findings indicate that TSS and weight of berries were statistically lower under vines pruned to 8 buds, $20.1^{\circ}$ Brix and $168 \mathrm{~g}$, respectively. Similar conclusions were found by Khamis et al. (2017), that less buds per cane had enhancing influence on these parameters. In addition, the results of Tangolar et al. (2015) indicate that sugar and organic acid content of the berries were not significantly differentiated by bud load effect. However, Leão and Lima (2017) concluded that effect of shoot and cluster density was depended on cultivars. In grapes of 'Thompson Seedless' the content of soluble solids was higher under lower shoot and bunch densities, while no impact of treatments was observed in 'Sugraoen' grapes. On the other hand, considering polyphenol compounds, our results showed that the lightest pruning intensity of 'Regent' led to their greatest concentration in berries (644 mg $\left.100 \mathrm{~g}^{-1} \mathrm{FW}\right)$.

\section{Elemental composition}

In the foregoing state of knowledge, very few research papers evaluated the effect of pruning on vine nutrient status. However, according to our results, pruning intensity altered elemental composition of berries. Figure 2 shows the average of macronutrient content ( $\mathrm{Ca}$, $\mathrm{K}, \mathrm{Mg}, \mathrm{N}$ and $\mathrm{P}$ ) in berries of 'Regent' from vines treated with different pruning intensity during three years of study (2013-2015). The most abundant element was potassium (K), followed by nitrogen $(\mathrm{N})$, phosphorus $(\mathrm{P})$, calcium $(\mathrm{Ca})$ and magnesium $(\mathrm{Mg})$. It should be emhpasised that the treatment had statistically significant meaning for the concentration of all macronutrients in berries. In contradiction, as reported by Pérez-Bermúdez et al. (2016), light pruning, next to cover crops, did not alter the foliar N, P, K concentrations of 'Bobal' and 'Tempranillo' cultivars, which were similar to those found in leaves from vines with soil tillage or severe pruning. In our experiment, higher intensity of pruning led to a greater accumulation of most tested macroelements. This tendency was especially evident for $\mathrm{N}$ and $\mathrm{Ca}$, in which cases 4 buds per cane resulted in the highest level of these nutrients, 6.62 and $1.12 \mathrm{~g} \cdot \mathrm{kg}^{-1}$ respectively. The only exception occurred for $\mathrm{K}$, where increasing of pruning intensity led to decreasing of its concentration. Thereupon, 4 buds per cane diminished potassium level to $10.97 \mathrm{~g} \cdot \mathrm{kg}^{-1}$, while 8 buds per cane enhanced its to $13.30 \mathrm{~g} \cdot \mathrm{kg}^{-1}$.

The average data obtained during three years of study (2013-2015) from the analyses of micronutrients ( $\mathrm{Cu}, \mathrm{Fe}, \mathrm{Mn}$ and $\mathrm{Zn})$ and heavy metals $(\mathrm{Cd}, \mathrm{Pb})$ in berries of cultivar 'Regent' harvested from the vines treated with various pruning level, is presented in Fig. 3. Berries were the most abundant in Fe, then followed by $\mathrm{Zn} \geq \mathrm{Mn}>\mathrm{Cu}>\mathrm{Pb}>\mathrm{Cd}$. Similarly as by macroelements, all analysed microelements and heavy metals were affected by pruning with statistical meaning. However, cadmium was not analysed statistically by means of synthesis from years, due to its level being below device sensitivity $\left(<0.01 \mathrm{mg} \cdot \mathrm{kg}^{-1}\right)$ in 2015 . According to our findings, higher intensity of treatment resulted in increasing of $\mathrm{Mn}, \mathrm{Pb}$ and $\mathrm{Zn}$ content in berries. In turn, 8 buds was found as a enhancing of $\mathrm{Cu}$ and Fe level, 3.61 and $19.53 \mathrm{mg} \cdot \mathrm{kg}^{-1}$ respectively, in compare to 6 and 4 buds per cane. In addition, the lightest pruning intensity influenced iron level on approximately $30 \%$ higher level comparing to the heaviest treatment. 
$\mathrm{Ca}\left[\mathrm{g} \cdot \mathrm{kg}^{-1}\right]$

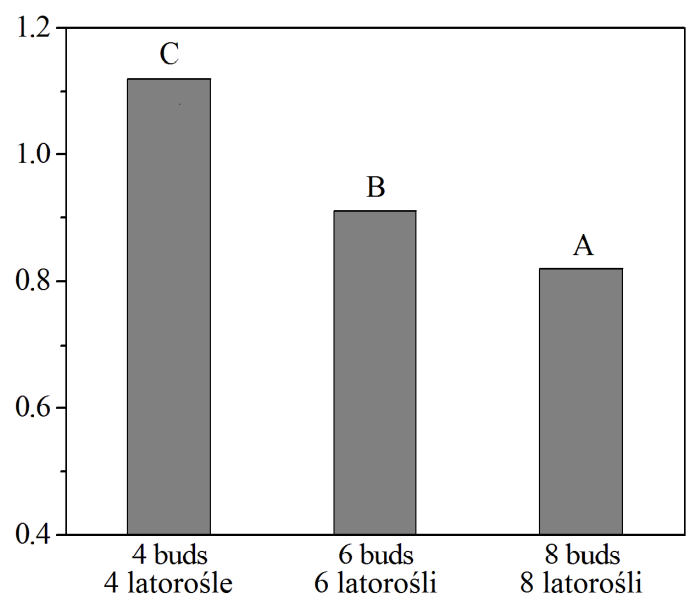

$\mathrm{Mg}\left[\mathrm{g} \cdot \mathrm{kg}^{-1}\right.$ ]

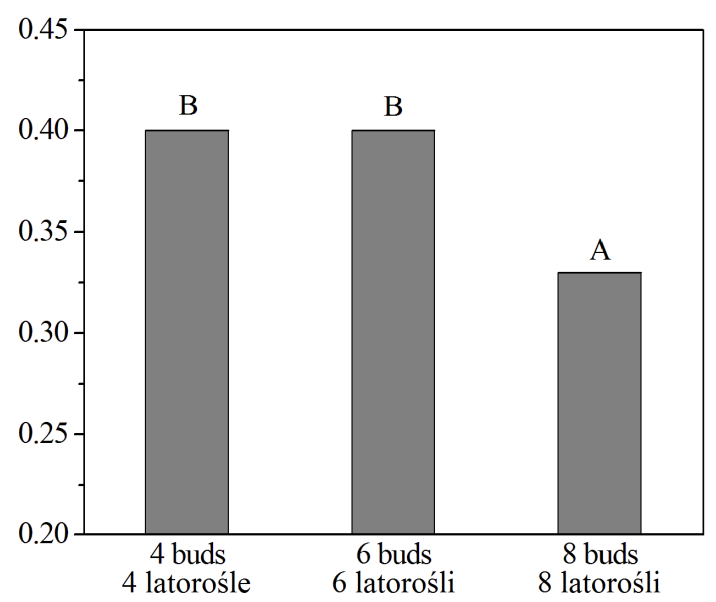

$\mathrm{K}\left[\mathrm{g} \cdot \mathrm{kg}^{-1}\right]$

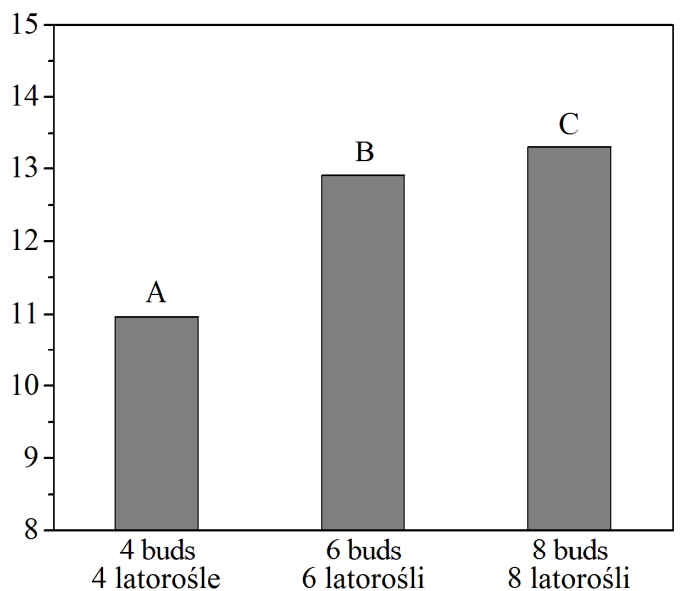

$\mathrm{N}\left[\mathrm{g} \cdot \mathrm{kg}^{-1}\right]$

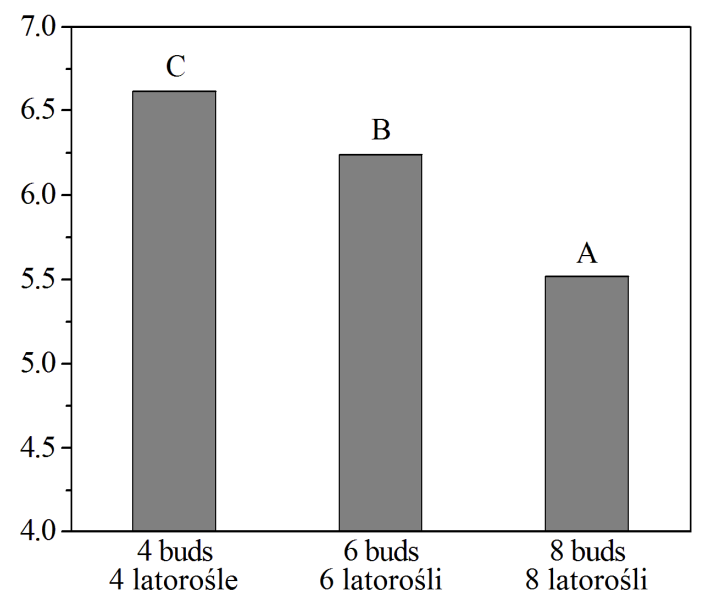

$\mathrm{P}\left[\mathrm{g} \cdot \mathrm{kg}^{-1}\right]$

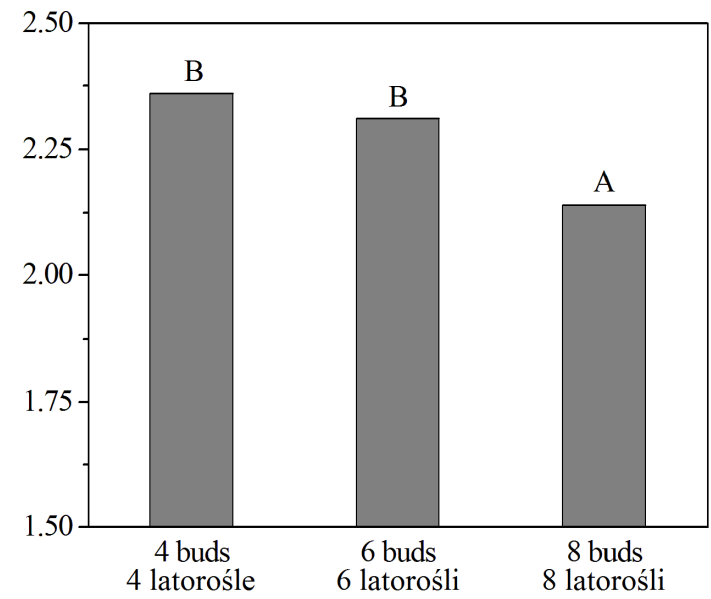

Fig. 2. Macronutrients of 'Regent' berries depending on vine pruning intensity (bud load level per cane: $4,6,8)$; as the average of years 2013-2015. Means having same letter were not significantly different by Tukey's comparison at $p<0.05$ level

Ryc. 2. Zawartość makroelementów w winogronach odmiany 'Regent' w zależności od intensywności cięcia winorośli (liczba latorośli na łozie: 4, 6, 8); średnia z lat 2013-2015. Średnie oznaczone tymi samymi literami nie różniły się istotnie według testu Tukeya na poziomie $p<0,05$ 
$\mathrm{Cu}\left[\mathrm{mg} \cdot \mathrm{kg}^{-1}\right]$

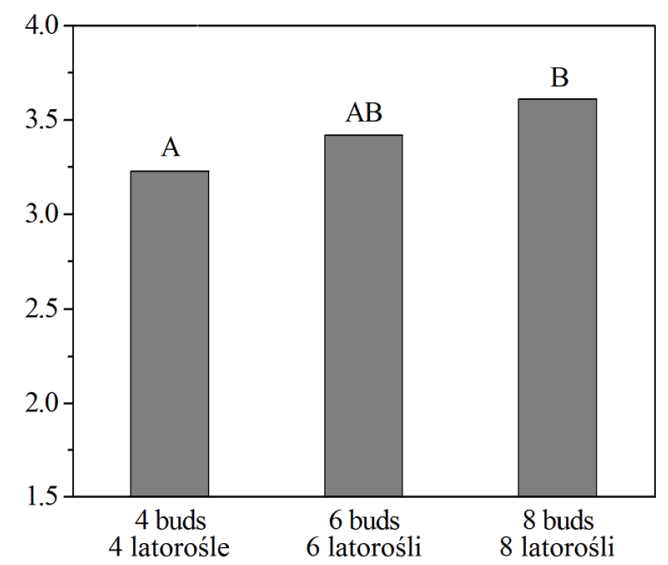

$\mathrm{Mn}\left[\mathrm{mg} \cdot \mathrm{kg}^{-1}\right]$

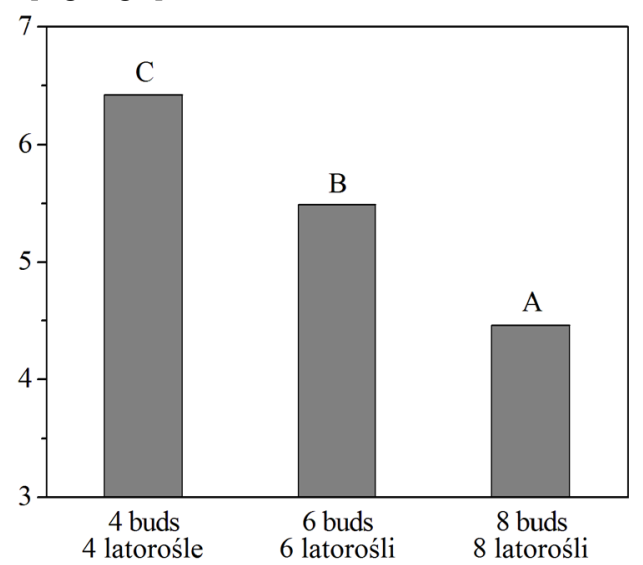

$\mathrm{Cd}\left[\mathrm{mg} \cdot \mathrm{kg}^{-1}\right]$

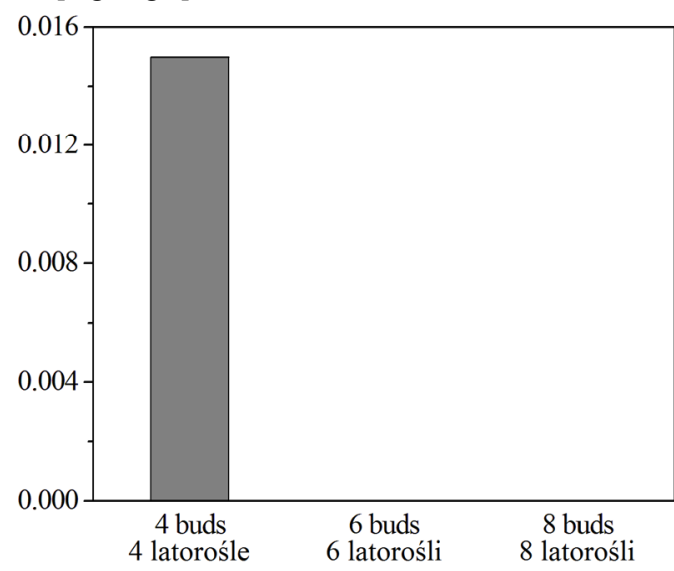

$\mathrm{Fe}\left[\mathrm{mg} \cdot \mathrm{kg}^{-1}\right]$

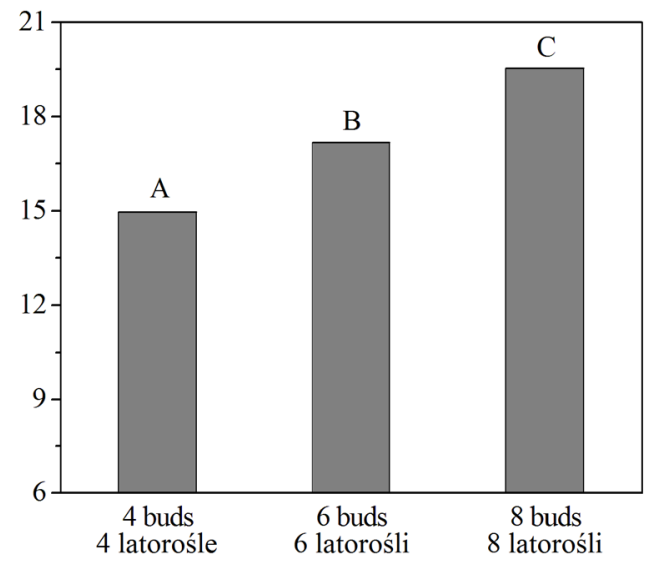

$\mathrm{Zn}\left[\mathrm{mg} \cdot \mathrm{kg}^{-1}\right]$

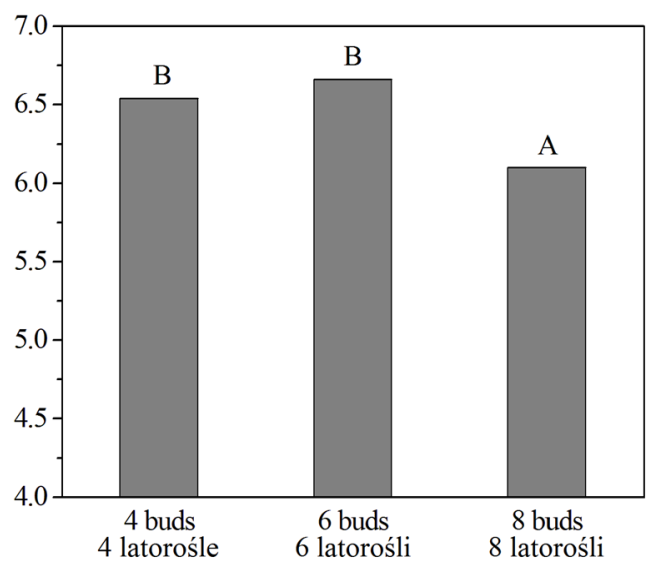

$\mathrm{Pb}\left[\mathrm{mg} \cdot \mathrm{kg}^{-1}\right]$

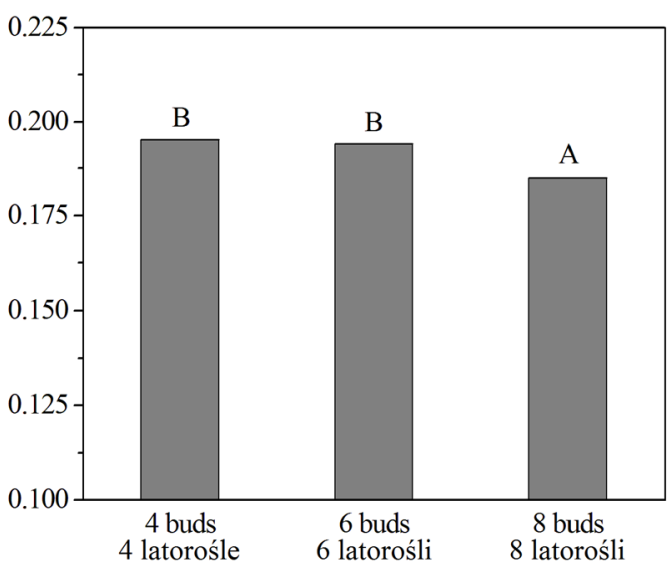

Fig. 3. Micronutrients and heavy metals of 'Regent' berries depending on vine pruning intensity (bud load level per cane: 4, 6, 8); as the average of years 2013-2015. Cadmium was not analysed statistically by means of synthesis from years, due to its level being below device sensitivity $\left(<0.01 \mathrm{mg} \cdot \mathrm{kg}^{-1}\right)$ in 2015. Means having same letter were not significantly different by Tukey's comparison at $p<0.05$ level Ryc 3. Zawartość mikroelementów i metali ciężkich w winogronach odmiany 'Regent' w zależności od intensywności cięcia winorośli (liczba latorośli na łozie: 4, 6, 8); średnia z lat 2013-2015. W przypadku kadmu nie wykonano analizy statystycznej na podstawie syntezy z poszczególnych lat z powodu jego poziomu poniżej czułości aparatury badawczej $\left(<0,01 \mathrm{mg} \cdot \mathrm{kg}^{-1}\right)$ w 2015. Średnie oznaczone tymi samymi literami nie różniły się istotnie według testu Tukeya na poziomie $p<0,05$ 


\section{CONCLUSIONS}

In this research, cane pruning intensity of vine cultivar 'Regent' showed a great impact on the quality of berries grown in cool climate condition of Poland. Most of tested attributes of berries were significantly affected by bud load number per cane, with the exceptions of cluster weight, titratable acidity and $\mathrm{pH}$. $\mathrm{Ca}, \mathrm{N}$ and $\mathrm{Mn}$ elements increased linearly with statistical meaning as the severity of pruning increased. Heavier pruning intensity enhanced weight of 100 berries, total soluble solids, Mg, P, Pb and $\mathrm{Zn}$ contents as well. In turn, 8 buds per cane led to the greatest level of polyphenols, K, Cu and Fe in berries of 'Regent'.

\section{REFERENCES}

Baiano A., Terracone C. 2012. Effects of bud load on quality of Beogradska besemena and Thompson seedless table grapes and cultivar differentiation based on chemometrics of analytical indices. J. Sci. Food Agric. 92, 645-653.

Bhosale S.S., Nalage N.A., Ghadge P.U., Magar S.D. 2010. Effect of cane pruning on growth, yield and quality of grape varieties under Buldana district. Inter. J. Agric. Sci. 6(1), 105-109.

Bindon K.A., Dry P.R., Loveys B.R. 2008. The interactive effect of pruning level and irrigation strategy on grape berry ripening and composition in Vitis vinifera L. cv. Shiraz. S. Afr. J. Enol. Vitic. 29(2), 71-78.

Brighenti A.F., Cipriani R., Malinovski L.I., Vanderlinde G., Allebrandt R., Feldberg N.P., Silva A.L. 2017. Ecophysiology of three Italian cultivars subjected to two pruning methods in Santa Catarina, Brazil. Acta Hortic. 1157, 381-388.

Coletta A., Berto S., Crupi P., Cravero M.C., Tamborra P., Antonacci D., Daniele P.G., Prenesti E. 2014. Effect of viticulture practices on concentration of polyphenolic compounds and total antioxidant capacity of Southern Italy red wines. Food Chem. 152, 467-474.

Dobrei A., Dobrei A., Posta G., Danci M., Nistor E., Camen D., Mălăescu M., Sala F. 2016. Research concerning the correlation between crop load, leaf area and grape yield in few grapevine varieties. Agric. Agric. Sci. Proc. 10, 222-232.

Drenjančević M., Jukić V., Zmaić K., Kujundžić T., Rastija V. 2017. Effects of early leaf removal on grape yield, chemical characteristics, and antioxidant activity of grape variety Cabernet Sauvignon and wine from eastern Croatia. Acta Agr. Scand. B.-S. P. 67(8), 705-711.

Fawzi M.I.F., Shahin M.F.M., Kandil E.A. 2010. Effect of bud load on bud behavior, yield, cluster characteristics and some biochemical contents of the cane of crimson seedless grapevines. J. Am. Sci. 6(12), 187-194.

Heazlewood J.E., Wilson S., Clark R.J., Gracie A.J. 2006. Pruning effects on Pinot Noir vines in Tasmania (Australia). Vitis 45(4), 165-171.

IUNG. 1990. Zalecenia nawozowe. Cz. I. Liczby graniczne do wyceny zawartości makro- i mikroelementów w glebach [Fertilization recommendations. Part I. Threshold values for determination of macro- and micronutrients in soils]. Pr. IUNG Puławy, Ser. P (44), 26. [in Polish]

Keller M. 2010. Managing grapevines to optimise fruit development in a challenging environment: a climate change primer for viticulturist. Aust. J. Grape Wine Res. 16, 56-69.

Keller M., Mills L.J., Harbertson J.F. 2012. Rootstock effects on deficit-irrigated winegrapes in a dry climate: vigor, yield formation, and fruit ripening. Am. J. Enol. Vitic. 63(1), 29-39.

Khamis M.A., Atawia A.A.R., El-Badawy H.E.M., Abd El-Samea A.A.M. 2017. Effect of buds load on growth, yield and fruit quality of superior grapevines. Middle East J. Agric.Res. 6(1), 152-160. 
Kumar A.R., Parthiban S., Subbiah A., Sangeetha V. 2017. Effect of pruning severity and season for yield in grapes (Vitis vinifera L.) variety muscat Hamburg. Int. J. Curr. Microbiol. App. Sci. 6(3), 1814-1826.

Kurtural S.K., Dami I.E., Taylor B.H. 2006. Effects of pruning and cluster thinning on yield and fruit composition of 'Chambourcin' grapevines. Hort. Technol. 16(2), 233-240.

Leão P.C.D.S., Lima M.A.C. 2017. Effect of shoot and bunch density on yield and quality of 'Sugraone' and 'Thompson Seedless' table grapes. Rev. Bras. Frutic. 39(4), e-828.

Mijowska K., Ochmian I., Oszmiański J. 2017. Rootstock effects on polyphenol content in grapes of 'Regent'cultivated under cool climate condition. J. Appl. Bot. Food Qual. 90, 159-164.

Oszmiański J., Kolniak-Ostek J., Wojdyło A. 2013. Characterization and content of flavonol derivatives of Allium ursinum L. plant. J. Agric. Food Chem. 61(1), 176-184.

Pérez-Bermúdez P., Olmo M., Gil J., García-Férriz L., Olmo C., Boluda R., Gavidia I. 2016. Cover crops and pruning in Bobal and Tempranillo vineyards have little influence on grapevine nutrition. Sci. Agric. 73(3), 260-265.

Robinson J., Harding J. 2015. The Oxford companion to wine, 4th ed. Eds. J. Robinson, J. Harding. Oxford University Press, 588.

Tangolar S., Tarım G., Kelebek H., Tangolar S.G., Topçu S. 2015. The effects of bud load and regulated deficit irrigation on sugar, organic acid, phenolic compounds and antioxidant activity of Razakı table grape berries. BIO Web of Conferences. EDP Sciences 5, 01002.

Abstract. The research were focused on the assessment of quality attributes of berries cultivar 'Regent'. The vines trained on Single Guyot training system were pruned at three intensities of 4 , 6 or 8 buds per cane. Berries were harvested in three consecutive seasons (2013-2015) at the research station of West Pomeranian University of Technology Szczecin in Poland. 'Regent' grapes were analysed in terms of physical and chemical attributes, i.e. weights of clusters and 100 berries, total soluble solids, titratable acidity, $\mathrm{pH}$, polyphenols, nutrients $(\mathrm{Ca}, \mathrm{Cu}, \mathrm{Fe}, \mathrm{K}, \mathrm{Mg}$, $\mathrm{Mn}, \mathrm{N}, \mathrm{P}, \mathrm{Zn})$ and heavy metals $(\mathrm{Cd}, \mathrm{Pb})$. Our results showed that cane pruning intensity of vine cultivar 'Regent' had significant influence on the quality of berries, with the exceptions of cluster weight, titratable acidity and $\mathrm{pH}$. Weight of 100 berries, total soluble solids and most of elements increased as the intensity of pruning increased. In turn, the lightest pruning treatment led to the greatest polyphenol, $\mathrm{K}, \mathrm{Cu}$ and $\mathrm{Fe}$ contents in berries. 